\title{
RESEARCH ANALYSIS OF SOCIAL MEDIA USAGE: ASSESSMENT OF ISSUES PERTAINING TO YOUTH SOCIAL NETWORKING USAGE AND THE CONSEQUENT IMPACT ON THEIR SOCIAL INTERACTIONS AND SOCIAL BEHAVIOR
}

\author{
Shaikh Mubbashar M. \\ Undergrad $3^{\text {rd }}$ year Btech (CSE) \\ PES College of Engineering Aurangabad, \\ Maharashtra, India
}

\author{
Mahajan Anand Shesherao \\ Undergrad $3^{\text {rd }}$ year Btech (CSE) \\ PES College of Engineering Aurangabad, \\ Maharashtra, India
}

\begin{abstract}
In the era of technology, social networking is at its peak. With emergence of various social networking platforms, addiction has become the main issue of mental health in society. The purpose of the paper is to explore the imposition of the virtual life over the reality. In effect to its users being rendered to extreme level of dependency and obsession over social media. The study mainly researches on the ongoing scenario of the present day involvement in social media world. The notion presented in the paper is based on the comprehensive research and literature review. The aim of the study is to create awareness of ill-effects to health because excessive use \& to monitor the usage pattern of media to its best possible advantage.
\end{abstract}

Keywords: Social media, depression, mental health

\section{INTRODUCTION}

With the evolution of civilization, its ability to create, organize, share, access \& retrieve information has expanded exponentially. It was predicated by the experts that by 2020 information will be doubled every seventy three days. Number of platforms have emerged for exchange \& sharing of this information known as social media networks. Social media is a common virtual platform for people to interact \& build relations across the globe. Social media has played a core role in transforming the lifestyle of people. It has found its way in every aspect by providing an interface for exchange and sharing of the information, ideas, and strategies and much more regardless of age, gender or region. The different networking sites have given a new dimension in the standard of living. While, it cannot be denied that it has provided greater benefits and a wide platform for communication, recent studies have shown that the overinvolvement of these social media has caused a severe adverse effect on the mental health \& overall personality of the young generation especially teens.

In principle studies showing how youth has engaged these social media sites in their day to day life. Extensive literature available, research \& surveys studies the impact of social media on people, especially younger generations. Research shows that the excessive use can lead to dysfunctional motor senses, inability to perform well in academics, poor job performance, and lack of stability in relationships, deprivation \& loss of self worth. The resultant is the withdrawal symptoms, depression and compulsive online addiction (Van den Eijnden et al. 2016). Several surveys were conducted which concluded that social media has greatly overpowered the ability to rule the human daily life. This in short is known as Social media addiction (SMA) which involves the use of media to such extent that there is inability to conduct the daily routine tasks without the interference of social media. Various surveys has been carried out to support the theory of SMA. Like the study of survey among 3000 US students from which $37 \%$ twitter 93\% used facebook (Dahlstrom, de Boor, Grunwaald, \& Vokley, 2011). As of current one third of the world population is involved excessively in social media.

While online compulsive addiction has been examined to great extent (Ha et al, 2007; Hawi, 2012: Tsitsika et al, 2014; Young, 1998), recently researchers has started investigation on impacts of various social media \& number of articles, studies have come forward supported by the experiments conducted, data collected and evaluated. A review of 2014 concluded in that there is relation between the symptoms of addiction like depression, negative consequences, withdrawal and use of social media. This gave 


\section{International Journal of Engineering Applied Sciences and Technology, 2020 \\ Vol. 5, Issue 7, ISSN No. 2455-2143, Pages 265-270 \\ Published Online November 2020 in IJEAST (http://www.ijeast.com)}

way to a new debate on the psychological ill effects and new studies were done. Number of studies investigated on antecedents of SMA \& studies mainly focused on the effects like withdrawal symptoms, personality traits \& self esteem due to SMA (Oldmeadow et al. 2013; Tosun and Lajunen 2010; Barelds 2005.) The present study aims to explore the research and extend the study on how \& to what extend the social media effects on social life.

\section{LITERATURE}

Studies on media activity \& its related effect on youth is continuously going but still is less in supply. The present study summarizes the research study to date. Despite of some differences most studies shows a negative correlation between the time spend on social media and the daily personality traits. Most of these studies are based on self reported data and cross-sectional related data sources. The findings, result $\&$ discussion are based on the secondary data collected. ${ }^{[3]}$

Different SM platforms \& general statistics of their usage:

- Facebook: 2.271 billion users

- Instagram: 1 billion users

- Youtube: $\mathbf{1 . 8}$ billion users

- WhatsApp: 900 million users

- LinkedIn: 562 million users

- $\quad$ Reddit: $\mathbf{5 4 2}$ million users

- Twitter: 326 million users

- Pinterest: 200 million users

- Snapchat: 186 million daily users

- Airbnb: 150 million users

- Google+: 111 million users

- Flickr: 90 million users

- 4Chan: 22 million

\begin{tabular}{|c|c|c|c|}
\hline \multicolumn{4}{|c|}{ Social media usage trend in India: } \\
\hline $\begin{array}{c}\text { Social } \\
\text { Networking } \\
\text { Sites }\end{array}$ & Monthly Visits & $\begin{array}{c}\text { Mobile } \\
\text { Traffic } \\
\text { Share }\end{array}$ & $\begin{array}{c}\text { Desktop } \\
\text { Traffic } \\
\text { share }\end{array}$ \\
\hline Facebook & 1.6 billion & $99.2 \%$ & $0.75 \%$ \\
\hline Youtube & 1.2 billion & $59.96 \%$ & $40.04 \%$ \\
\hline Quora & 215.8 million & $98.89 \%$ & $1.11 \%$ \\
\hline Instagram & 191.1 million & $99.02 \%$ & $0.98 \%$ \\
\hline Twitter & 125.2 million & $97.81 \%$ & $2.19 \%$ \\
\hline Pinterest & 49.8 million & $98.40 \%$ & $1.60 \%$ \\
\hline LinkedIn & 29.9 million & $90.97 \%$ & $9.03 \%$ \\
\hline
\end{tabular}

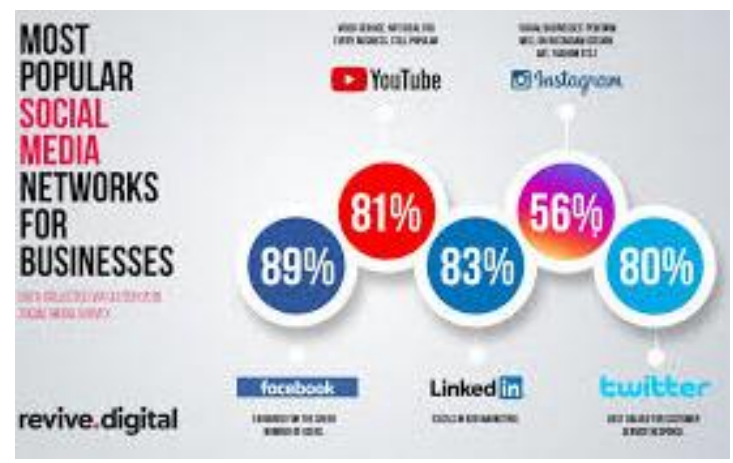

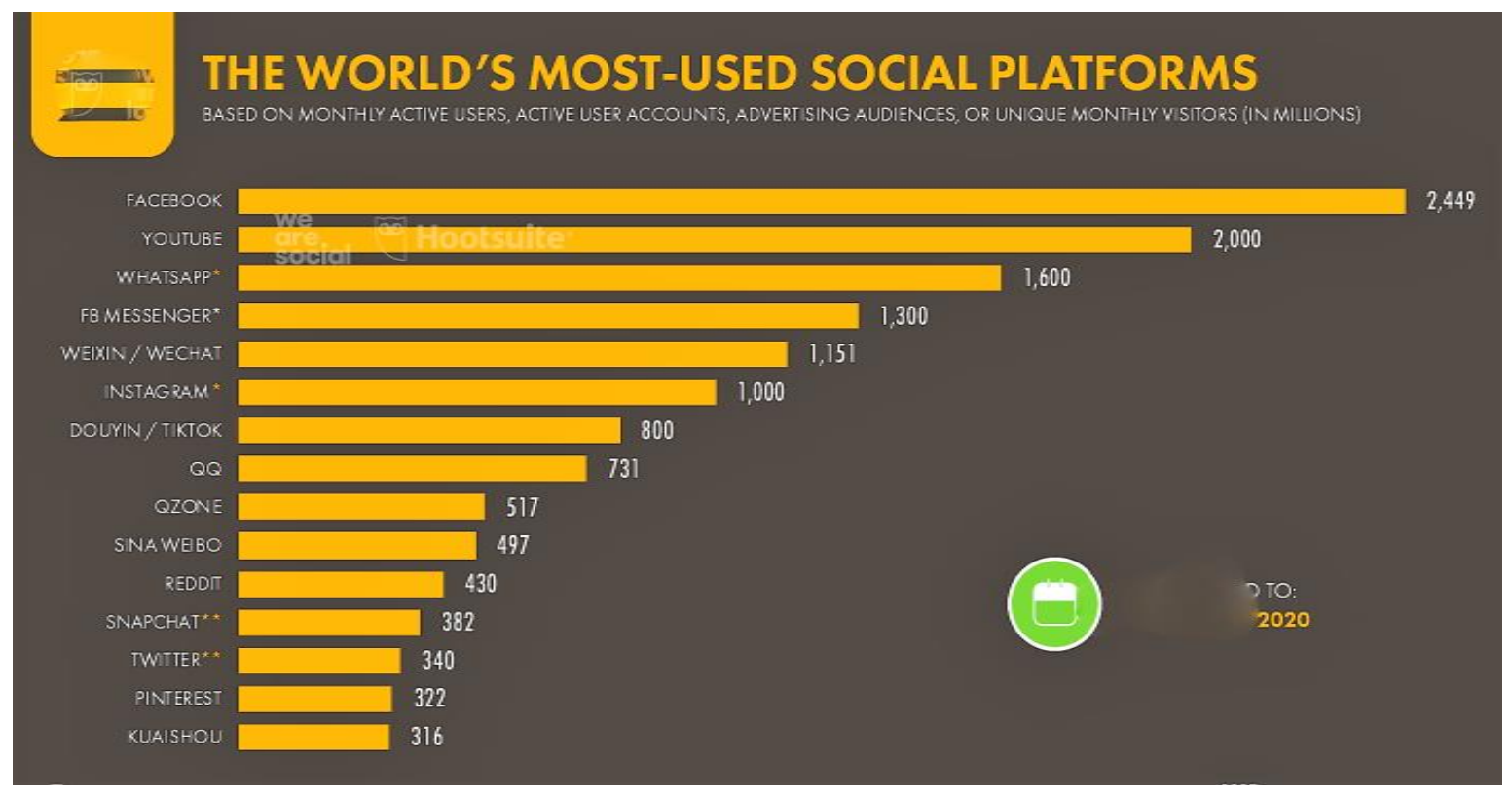




\section{International Journal of Engineering Applied Sciences and Technology, 2020 \\ Vol. 5, Issue 7, ISSN No. 2455-2143, Pages 265-270 \\ Published Online November 2020 in IJEAST (http://www.ijeast.com)}

\section{TOLL ON MENTAL HEALTH DUE TO SM}

When the consumption of media exceeds its limit, its results in negative outcomes and addictive behavior. (Griffiths et al. 2016) especially in youth and adolescents. (World Health Organization 2011). Some scholars claimed that communication through these virtual media has become easier for the youth nd individual to engage in unhealthy dysfunctional and addictive social behavior (Kuss and Griffiths 2017). These activities have become excessive resulting delirious behavior. ${ }^{[1]}$ Every year the percentage of SM increases than the year before. As of study in 2017 , there is an average increase of $9 \%$ use of SM from previous year (from $126 \mathrm{~min} /$ day to $135 \mathrm{~min} /$ day) (Statista 2017). [2] SM:

Enlisted below are some types of psychological effects due to

- $\quad$ FOMO effect: Also known as fear of missing out is another mental health effect due to social media. Psychology experts explain FOMO effect as a larger issue of inclusion and social standing. The current research shows that $67 \%$ have reported their inability to cope up with the society issues. ${ }^{[4]}$

- Depression because of addiction: Many of us use media platforms like Facebook, Snapchat, Instagram, YouTube to find and connect each other. While it has its benefits it can't replace the real world relationships. The need for approval in society causes constant integrates a different identity than the original one. This has caused as much as $78 \%$ depression due to SM. Research on statistics the addiction of depression not only remains till comparison but also leads to ending of life. It requires in person contact to relieve the stress and release hormones which elevate the mood and brings positivity. As these are decrease due to the virtual media world, it has ultimately led to extreme levels of depression. The ability of what to post and not to share has opened gates to create online personas which are nothing like original identity, which ultimately leads to depression. The comparative study of depression in youth within the decade has been found to increase exponentially. [3]

- $\quad$ Frustration and agitation: The need to check every buzz has created a feeling of being constantly agitated, angry and annoyed.

- $\quad$ Decreased learning and research ability: Although online materials gives an ease in knowledge its has greatly decreased the thinking and understanding power .it has greatly reduced the uniqueness and creativity of youth due to over dependence on online information.
- Cyber-bullying: A major subject of issues of online media is cyber bullying. As much as $72 \%$ of adolescents have been reported to be cyber-bullied at some point in their life. This is more related to suicide attempts than face to face bullying. As it is online bullying rather than in person the person cant escape the situation. Moreover it cannot be controlled by the teachers or parents. Ultimately it creates helplessness in victims which more or less lead to suicide. ${ }^{[5]}$

- Obsession and disconnect from real relations: The researches in the study have observed that the people who are more connected to the online media are less sensitive toward the feelings of the other people around them. Such people are usually self-absorbed which we usually call as Narcissm (JeanM. Twenge, 2013). Narcissism usually leads to decreased empathy and concerns among the youth and teenagers. The youths more connected to online share unrequired excessive information which then results in negative outcomes. These often results in disruption in their personnel relationships. The need to connect with the virtual media overcomes with that of real relationships and results in obsessive behavioral patterns. [6].
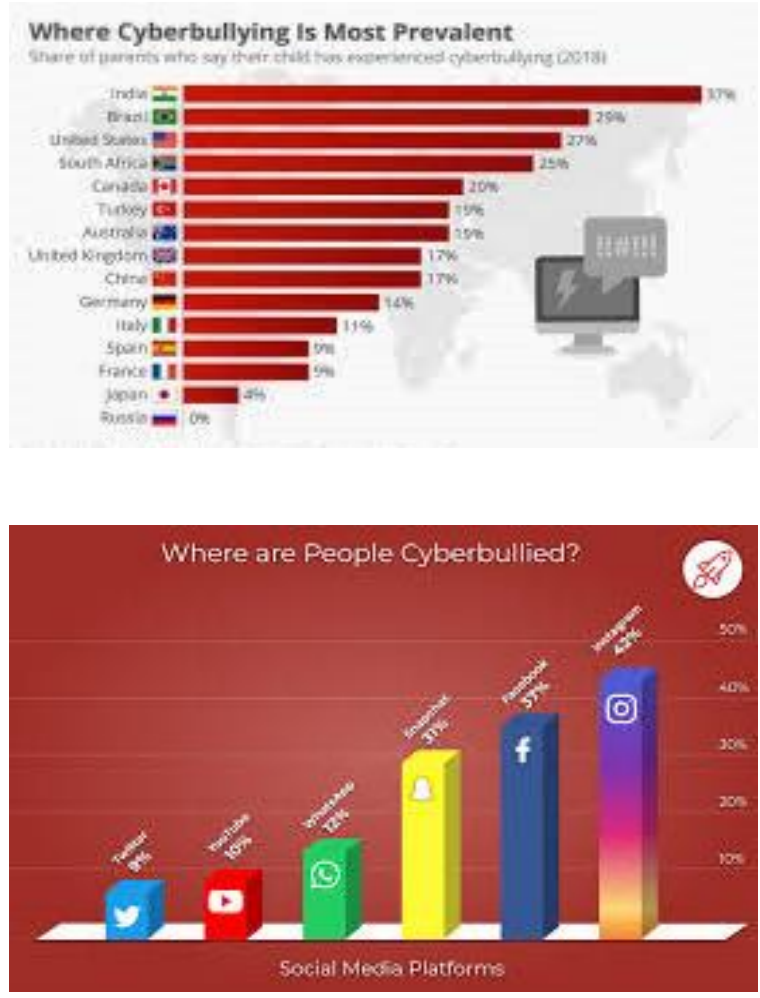


\section{International Journal of Engineering Applied Sciences and Technology, 2020 \\ Vol. 5, Issue 7, ISSN No. 2455-2143, Pages 265-270 \\ Published Online November 2020 in IJEAST (http://www.ijeast.com)}

\section{RESEARCH ANALYSIS ON SOCIAL MEDIA ADDICTION}

The following analysis was done based on the data collected \& evaluated from the different studies, articles, experimental models \& research. The different study methods were adapted for understanding the extent of addiction in the

\begin{tabular}{|c|c|c|c|}
\hline $\begin{array}{l}\text { Sr. } \\
\text { no. }\end{array}$ & Research & Study aim & $\begin{array}{c}\text { Sample / } \\
\text { Set }\end{array}$ \\
\hline 1 & $\begin{array}{c}\text { Effects of } \\
\text { attachment } \\
\text { styles, dark triad } \\
\text { rejection, } \\
\text { sensitivity and } \\
\text { relationship } \\
\text { satisfaction on } \\
\text { social media } \\
\text { addiction } \\
\end{array}$ & $\begin{array}{l}\text { To test the direct link of } \\
\text { adult insecurity } \\
\text { attachment in } \\
\text { relationship, rejection } \\
\text { sensitivity\& dark triad } \\
\text { personality with SMA }\end{array}$ & $\begin{array}{c}\text { The data } \\
\text { was } \\
\text { collected } \\
\text { from } 237 \\
\text { university } \\
\text { students } \\
\text { (76 males, } \\
161 \\
\text { female) } \\
\end{array}$ \\
\hline 2 & $\begin{array}{l}\text { Overall effects } \\
\text { on mental health }\end{array}$ & $\begin{array}{c}\text { Positive and negative } \\
\text { effects of social media on } \\
\text { mental health }\end{array}$ & $\begin{array}{c}\text { Data } \\
\text { collected } \\
\text { from } 350 \\
\text { youths } \\
\text { aged } \\
\text { between } \\
12-24\end{array}$ \\
\hline 3 & $\begin{array}{l}\text { Neurological } \\
\text { effects of media } \\
\text { addiction }\end{array}$ & $\begin{array}{c}\text { Neuroticism and Facebook } \\
\text { Addiction: }\end{array}$ & $\begin{array}{c}\text { Original } \\
\text { sample of } \\
856 \\
\text { participant } \\
\text { s (534 } \\
\text { females, } \\
322 \\
\text { males) } \\
\end{array}$ \\
\hline 4 & $\begin{array}{c}\text { Effect on } \\
\text { Academic } \\
\text { performance }\end{array}$ & $\begin{array}{l}\text { Engagement and } \\
\text { Addiction as Predictors of } \\
\text { Academic Performance }\end{array}$ & $\begin{array}{c}\text { Total } \\
\text { sample } \\
=1327 \\
\text { students }\end{array}$ \\
\hline 5 & $\begin{array}{l}\text { Liberatore et al. } \\
\text { (2011) }\end{array}$ & $\begin{array}{l}\text { study of prevalence of } \\
\text { Internet addiction in } \\
\text { adolescents receiving } \\
\text { treatment for a diagnosed } \\
\text { psychiatric illness }\end{array}$ & $\begin{array}{c}\mathrm{N}=71 \\
\text { adolescent } \\
\text { outpatient } \\
\text { s in Puerto } \\
\text { Rico, } \\
\text { Latin } \\
\text { America } \\
\text { (age range } \\
=13-17 \\
\text { years) }\end{array}$ \\
\hline $\begin{array}{l}\text { Sr. } \\
\text { no. }\end{array}$ & Design/Method & Addiction Measures & $\begin{array}{c}\text { Pervasive } \\
\text { ness }\end{array}$ \\
\hline
\end{tabular}

society. The prevalence was then suggested at the end of each study or research depending upon the analysis and evaluation of the data collected from theses sample sets. ${ }^{[8]}$

\begin{tabular}{|c|c|c|c|}
\hline 1 & $\begin{array}{l}\text { Social media } \\
\text { addiction scale, } \\
\text { relationship } \\
\text { assessment scale }\end{array}$ & $\begin{array}{l}\text { Relationship assessment } \\
(\mathrm{r}=.13, \mathrm{p}<.05) \\
\text { Personality assessment } \\
(\mathrm{r}=-.23, \mathrm{p}<.01)\end{array}$ & $\begin{array}{l}\text { Preoccupi } \\
\text { ed \& } \\
\text { fearful } \\
\text { attachmen } \\
\text { t was } \\
\text { negatively } \\
\text { associated }\end{array}$ \\
\hline 2 & Survey method & $\begin{array}{l}\text { Self reported } \\
\text { questionnaires assessment }\end{array}$ & $\begin{array}{c}87 \% \\
\text { addicted } \\
\text { Inability } \\
\text { to focus } \\
\text { on } \\
\text { academis }\end{array}$ \\
\hline 3 & $\begin{array}{l}\text { Demographic } \\
\text { questionaire }\end{array}$ & $\begin{array}{l}\text { Pearson's bivariate } \\
\text { correlations of the } \\
\text { variables and controls }\end{array}$ & $\begin{array}{l}\text { The study } \\
\text { concludes } \\
\text { that } \\
\text { Facebook } \\
\text { addiction } \\
\text { acts as a } \\
\text { significant } \\
\text { mediator } \\
\text { in the } \\
\text { associatio } \\
\text { n between } \\
\text { neuroticis } \\
\text { m } \\
\text { and } \\
\text { negative } \\
\text { affect. }\end{array}$ \\
\hline 4 & $\begin{array}{c}\text { Social } \\
\text { Media } \\
\text { Addiction Scale } \\
\text { (SMAS) }\end{array}$ & $\begin{array}{l}\text { Social Media Engagement } \\
\text { Questionnaire (SMEQ) } \\
\text { with varimax rotation }\end{array}$ & $\begin{array}{l}\text { Results } \\
\text { show that } \\
\text { the } \\
\text { amount of } \\
\text { time one } \\
\text { spends } \\
\text { using } \\
\text { social } \\
\text { media } \\
\text { affects } \\
\text { academic } \\
\text { performan } \\
\text { ce in a } \\
\text { negative } \\
\text { way. }\end{array}$ \\
\hline 5 & $\begin{array}{l}\text { Cross-sectional } \\
\text { pen-and-paper } \\
\text { questionnaire }\end{array}$ & $\begin{array}{l}\text { Internet Addiction Test } \\
\text { (Young, 1998), scores } \\
\geq 80 / 100 \text { shows addiction }\end{array}$ & $\begin{array}{l}11.6 \% \\
\text { addicted }\end{array}$ \\
\hline
\end{tabular}




\section{Statistical analysis of \% addiction:}

\begin{tabular}{|c|c|c|}
\hline \multirow{2}{*}{$\begin{array}{c}\text { Social Media } \\
\text { Platform }\end{array}$} & \multicolumn{2}{|c|}{$\begin{array}{c}\text { \% addiction found between } \\
13-24 \text { years old }\end{array}$} \\
\cline { 2 - 3 } & 2010 & 2020 \\
\hline Facebook & 66 & 78 \\
\hline Snapchat & 73 & 83 \\
\hline Instagram & 82 & 81 \\
\hline Twitter & 42 & 51 \\
\hline Youtube & 88 & 95 \\
\hline
\end{tabular}

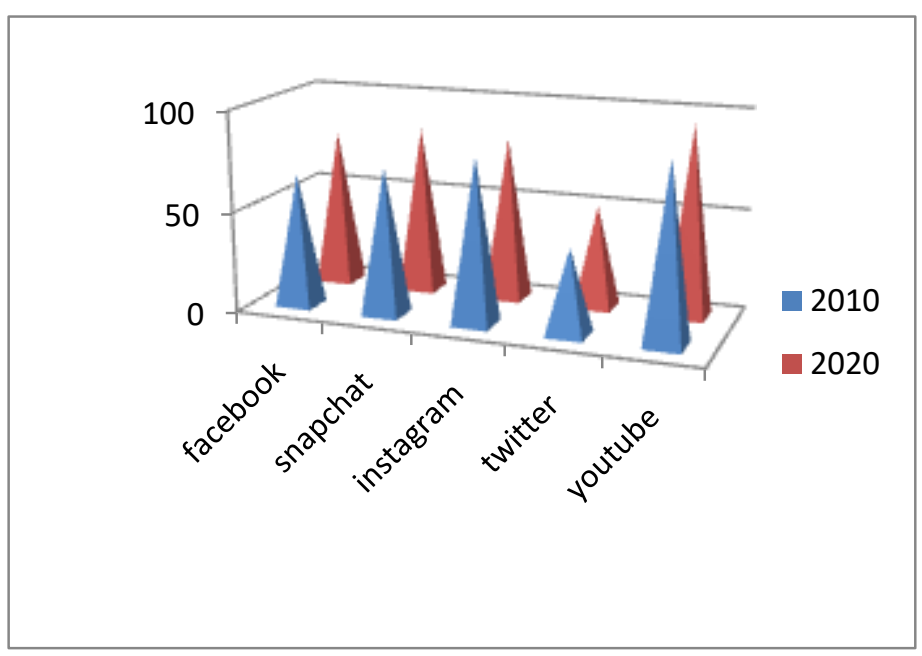

\section{CONCLUSION}

It cannot be denied that social networking sites have provided immense benefits in information sharing and learning. While access to different perspectives and diverse source of information is paramount to any independent democratic society, it cannot help people in grasping \& understanding the knowledge. the challenge of the current digital media is not how to create the information but how to sort, manage, enhance \& use in proper way. The study mainly focuses on social media usage and its effects on behavior on social life. The data collected \& evaluated, the result concludes that there direct relationship between the usage of the social media and development of addiction. The social media adddiction has a significant effect on the personality of the individual and greatly interferes with the day to day tasks involved. The objective of the study is to understand and help in further expanding and enhancing the ongoing research studies on the effects on mental health due to social media.

\section{REFERENCES}

1) Abbasi, I. and Drouin, M., 2019. Neuroticism and Facebook Addiction: How Social Media can Affect Mood?. The American Journal of Family Therapy, 47(4), pp.199-215.

2) Akram, W. and Kumar, R., 2017. A Study on Positive and Negative Effects of Social Media on Society. International Journal of Computer Sciences and Engineering, 5(10), pp.351-354.

3) Al-Menayes, J., 2015. Social Media Use, Engagement and Addiction as Predictors of Academic Performance. International Journal of Psychological Studies, 7(4), p.86.

4) Blackwell, D., Leaman, C., Tramposch, R., Osborne, C. and Liss, M., 2017. Extraversion, neuroticism, attachment style and fear of missing out as predictors of social media use and addiction. Personality and Individual Differences, 116, pp. 69-72.

5) D'Arienzo, M., Boursier, V. and Griffiths, M., 2019. Addiction to Social Media and Attachment Styles: A Systematic Literature Review. International Journal of Mental Health and Addiction, 17(4), pp.10941118.

6) Demircioğlu, Z. and Göncü Köse, A., 2020. Effects Of Attachment Styles, Dark Triad, Rejection Sensitivity, And Relationship Satisfaction On Social Media Addiction: A Mediated Model. [online] Earsiv.cankaya.edu.tr. Available at: <http://earsiv.cankaya.edu.tr:8080/handle/20.500.12 416/3806> [Accessed 7 December 2020].

7) Hawi, N. and Samaha, M., 2016. The Relations Among Social Media Addiction, Self-Esteem, and Life Satisfaction in University Students. Social Science Computer Review, 35(5), pp.576-586.

8) Kuss, D., van Rooij, A., Shorter, G., Griffiths, M. and van de Mheen, D., 2013. Internet addiction in adolescents: Prevalence and risk factors. Computers in Human Behavior, 29(5), pp.1987-1996.

9) Martynowska, K., 2018. Kimberly S. Young, Cristiano Nabuco de Abreu, Internet Addiction: A Handbook and Guide to Evaluation and Treatment, New Jersey: Johan Wiley\&Soons 2011. Roczniki Pedagogiczne, 10(46)(3), pp.154-156.

10) N, D., 2014. Rise and Use of New Media and its Relationship to Changing Values of Indian Youth. IOSR Journal of Humanities and Social Science, 19(9), pp.07-14.

11) Nakaya, A., 2015. Internet And Social Media Addiction. San Diego, CA: ReferencePoint Press, Inc. ${ }^{\circledR}$. 


\section{International Journal of Engineering Applied Sciences and Technology, 2020 \\ Vol. 5, Issue 7, ISSN No. 2455-2143, Pages 265-270 \\ Published Online November 2020 in IJEAST (http://www.ijeast.com)}

12) Rikzana A, A. and Neelamalar, M., 2020. WOMEN BASED PROGRAMS IN PUBLIC, PRIVATE AND COMMUNITY RADIO STATIONS AS A TOOL FOR WOMEN'S DEVELOPMENT: A STUDY IN CHENNAI, INDIA. ENSEMBLE, 2(1), pp.187-199.

13) Siddiqui, S. and Singh, T., 2016. Social Media its Impact with Positive and Negative Aspects. International Journal of Computer Applications Technology and Research, 5(2), pp.7175.

14) Sriwilai, K. and Charoensukmongkol, P., 2015. Face it, don't Facebook it: Impacts of Social Media Addiction on Mindfulness, Coping Strategies and the Consequence on Emotional Exhaustion. Stress and Health, 32(4), pp.427-434.

15) Young, K., 1999. Internet addiction: evaluation and treatment. BMJ, 319(Suppl S4), p.9910351.

16) Zivnuska, S., Carlson, J. R., Carlson, D. S., Harris, R. B., \& Harris, K. J. (2019). Social media addiction and social media reactions: The implications for job performance. The Journal of Social Psychology, 159(6),.doi:10.1080/00224545.2019.1578725 pp. 746-760

17) Flanigan, A. E., \& Babchuk, W. A. (2015). Social media as academic quicksand: A phenomenological study of student experiences in and out of the classroom. Learning and Individual Differences, 44, 40-45. doi:10.1016/j.lindif.2015.11.003

18) Brailovskaia, J., Rohmann, E., Bierhoff, H., Schillack, H. and Margraf, J., 2019. The relationship between daily stress, social support and Facebook Addiction Disorder. Psychiatry Research, 276, pp.167-174.

19) Foroughi, B., Iranmanesh, M., Nikbin, D. and Hyun, S., 2019. Are depression and social anxiety the missing link between Facebook addiction and life satisfaction? The interactive effect of needs and selfregulation. Telematics and Informatics, 43, p.101247.

20) Griffiths, M., 2012. Facebook Addiction: Concerns, Criticism, and Recommendations - A Response to Andreassen and Colleagues. Psychological Reports, 110(2), pp.518-520.

21) Hong, F. and Chiu, S., 2014. Factors Influencing Facebook Usage and Facebook Addictive Tendency in University Students: The Role of Online Psychological Privacy and Facebook Usage Motivation. Stress and Health, 32(2), pp.117-127.
22) Hong, F., Huang, D., Lin, H. and Chiu, S., 2014. Analysis of the psychological traits, Facebook usage, and Facebook addiction model of Taiwanese university students. Telematics and Informatics, 31(4), pp.597-606.

23) Mamun, M. and Griffiths, M., 2019. The association between Facebook addiction and depression: A pilot survey study among Bangladeshi students. Psychiatry Research, 271, pp.628-633.

24) Ryan, T. and Xenos, S., 2011. Who uses Facebook? An investigation into the relationship between the Big Five, shyness, narcissism, loneliness, and Facebook usage. Computers in Human Behavior, pp.1658-1664. 